\title{
Knowledge transfer among international strategic alliance partners and its impact on innovation performance
}

\author{
Vijita S. Aggarwal and Madhavi Kapoor* \\ USMS, \\ GGSIPU, \\ Room No. 101, Block D, Sector 16C, \\ Dwarka, New Delhi, 110078, India \\ Email: vijitasaggarwal@gmail.com \\ Email: madykapoor.4@gmail.com \\ *Corresponding author
}

\begin{abstract}
The purpose of this study is to provide an overview of the literature available on knowledge transfer highlighting the factors affecting knowledge transfer mechanism and provides a theoretical framework to study its impact on strategic alliance's innovation performance. The paper studied a vast literature for providing a comprehensive framework to study the knowledge transfer mechanism among the alliance partners and its impact on performance. It also proposes a methodology for future empirical testing. The paper provides factors affecting knowledge transfer among international strategic alliance partners. A theoretical framework is prepared from the literature for further research integrating factors effecting knowledge transfer, linking them with innovation performance. This paper provides avenues for further research in the field of strategic management and international business for improving knowledge exchange for alliance's success. The paper could not review all the possible variables affecting knowledge transfer and is conceptual in nature. The paper provides a useful insight for managers involved in the international strategic alliances as well as for business executives for improving knowledge transfer mechanism among alliance partners. Although various researchers have studied knowledge transfer among international strategic alliances, not too many have linked factors affecting knowledge transfer with performance, which this study does.
\end{abstract}

Keywords: knowledge transfer; international strategic alliances; innovation performance; absorptive capacity; knowledge-based assets; multinational enterprises; dynamic capabilities theory; sustainable competitive advantage; technology; learning intent.

Reference to this paper should be made as follows: Aggarwal, V.S. and Kapoor, M. (2019) 'Knowledge transfer among international strategic alliance partners and its impact on innovation performance', Int. J. Strategic Business Alliances, Vol. 6, No. 4, pp.203-216.

Biographical notes: Vijita S. Aggarwal is a Professor of International Business with the University School of Management Studies at GGS Indraprastha University, New Delhi, and one of the first recruitments done by the university (which was then only five months old). She remained involve in the establishment of the department, formulation of syllabi, conceiving, designing 
and launching new academic programs in sync with the requirements of the job market and compatibility with the requirements of the aspiring students. She has published papers in various journals and has spoken at various national and international conferences.

Madhavi Kapoor is a Research Scholar at the University School of Management Studies at GGS Indraprastha University, New Delhi. She completed her MBA from the same institution. She completed her Economics Hons from the Delhi University, New Delhi. She has published research papers with national and international journals, including Scopus indexed journals. Also, she has presented papers at national and international conferences.

\section{Introduction}

The global economy has witnessed the widespread formation of strategic alliances across all types of firms competing in all major sectors and industries. When international strategic alliances are formed, valuable learning opportunities are created which can give the results of an alliance as net positive or a zero-sum game, where the partner who can learn faster can dominate the relationship (Hamel, 1991). Despite the firms' efforts for protecting their knowledge, alliance involvements are said to inevitably result in knowledge spill-overs (Inkpen, 2000). Strategic alliance is a group of firms in a voluntary arrangement facilitating knowledge exchange, and sharing of other skills and know-how for effective production or development of technologies or services (Inkpen and Tsang, 2005). They can be thought of as a co-alignment between two or more firms in which partners seek to learn and acquire from each others' products, technologies, knowledge and skills which are not available to other firms, thus making alliances an organisational design to deal with various complexities and learning new sources of being globally competitive (Lei et al., 1997). One of the basic premises for succeeding in business internationally is having some advantageous knowledge-based asset (Inkpen, 2008). Kogut and Zandar also argued in 1993 that the existence of multinational enterprises depends upon their superiority as a means of transferring knowledge across nations (Love, 1995). Knowledge transfer differs for international and local strategic alliances as international strategic alliances involve firms of different nationalities thus differing largely in their culture, policies, procedures, language, etc. whereas local strategic alliances involve firms with much similar context thus easing the transfer process (Riege, 2007; Duan et al., 2010a).

According to the dynamic capabilities theory, contemporarily firms are aiming to attain sustainable competitive advantage via adopting policies, procedures, processes and resources which are subject to modifications as and when required (Teece et al., 1997; Teece, 2010, 2017). Knowledge has emerged as the most significant resource to attain competitive advantage in the present world of strategic alliances (Simonin, 1999b). Knowledge transfer has been defined by Easterby-Smith et al. (2008) as an event through which one firm learns from the experience of the other firms making it an important research area in the field of strategic management and international business in the case of multi-national firms involved in knowledge transfer. Knowledge transfer brings a change in the behaviour of the recipient and may lead to development of new ideas resulting in organisational learning which brings a change in the organisational outcomes 
in terms of performance like innovation, operational, financial, etc. (Davenport et al., 1998; Minbaeva et al., 2003).

The knowledge transfer in case of international strategic alliances involves the exchange of technology, management expertise and global support (Inkpen and Beamish, 1997). Knowledge transfer depends upon the ease of transferability, interpretation and absorption of the knowledge (Hamel et al., 1989). This paper will be focussing on a special case of multinational enterprises, i.e., international strategic alliances for analysing knowledge transfer among the partners which help them in attaining competitive advantage over other firms. The study also tries to propose an integrated research framework based on the theory of dynamic capabilities

\section{Literature review}

Strategic alliances are formed for various motives which can be broadly categorised into three motives (Vaidya, 2009):

1 Internal benefits: Involves risk and cost sharing, gaining scarce resources, financing, information, internalising managerial know-how and retaining valuable employees as suggested by transaction cost theory and resource-based theory (Grant, 1991; Young-Ybarra and Wiersema, 1999).

2 Competitive benefits: Gaining sustainable competitive advantage which includes influence over industry structures, responding to global and national policy changes. This view incorporates the latest dynamic capabilities theory (Teece et al., 1997; Teece, 2010).

3 Strategic benefits: Involves creation and exploitation of technology transfer, synergies of alliance and diversification. This incorporates the knowledge-based view of the strategic management models (Kogut and Zander, 1992; Yli-Renko et al., 2001).

There are various approaches to strategic management models, like transaction cost approach, resource-based approach, knowledge-based approach and dynamic capabilities approach, as suggested in the above mentioned points. But all these approaches refer to the importance of knowledge management, especially knowledge transfer to attain the ultimate motive of sustainable competitive advantage (Teece, 2017).

John Child has identified three types of organisational learning while studying joint venture management in China (Madhok and Phene, 2003):

1 Technical learning: Involving acquisition and application of new techniques like TQM.

2 Systematic learning: Involving operationalisation of new systems and procedures like production control, assigning clearly defined roles and responsibilities, budgeting systems, etc.

3 Strategic learning: Involving senior management for collaborating their business success ideas and factors for achieving sustainable competitive advantage. 
Another definition of knowledge transfer in organisations is given by Argote and Ingram (2000) which refers to it as a process through which one entity/department/division learns or gets effected by the experience of others.

Knowledge is created and organised by the flow of information (Nonaka, 1994). Following are the explanation of various factors affecting knowledge transfer among international strategic alliances.

\subsection{Knowledge tacitness}

Polanyi (1966, p.4) classified human knowledge as 'explicit' which can be easily codifiable and can be transmitted in formal and systematic language and 'tacit' which is hard to codify, formalise and communicate because of its nature of being deeply rooted and involved in a specific context (Nonaka, 1994). Researchers explain tacitness as a feature where an entity knows more than it can explain. Some competencies are accumulated with experience, learnt by doing and refined by practice because it includes a high proportion of tacit knowledge which is difficult to codify and transfer (Reed and Defillippi, 1990). Grant (1996) admits that the organisational knowledge transfer is difficult if most of the knowledge is tacit in nature (Simonin, 1999a). In many cases, transfer of tacit knowledge is feasible only through close observation, demonstration and hands-on experience, thus require greater efforts (Reagans and Mcevily, 2003). Zander and Kogut (1995) showed that the explicit knowledge which can be codified is easily transferable as compared to tacit knowledge. Lord and Ranft (1998) studied the effect of communication system, tacitness of knowledge and organisational structure on knowledge transfer and showed the negative effect of tacitness of knowledge on the effectiveness of knowledge transfer (Kang et al., 2010). Following the work of Kogut and Zander (2003), Wang and Zhang (2009) studied the medium-sized enterprises in China to analyse the network perspective of inter-organisational learning and included tacitness as an important dimension and designed its items to measure the degree to which knowledge can be articulated in documents. Another study on Chinese small and medium-sized enterprises has unravelled the complex linkages between the knowledge properties and innovation performance and found the negative impact of knowledge tacitness on the innovation performance of the firms (Wang and Han, 2011).

\subsection{Learning intent}

In an inter-organisational setup, Hamel (1991) defined the learning intent as the desire, will and determination of the firm to learn from its partner. Mowery et al. (1996) defined learning intent as the aspiration to learn the firm's knowledge. Simonin (2004) refer to it as the degree of desire to internalise the knowledge, skills and competencies of the alliance partner. He empirically investigated the process of knowledge transfer in international strategic alliances and took learning intent as an important factor affecting the knowledge transfer by proposing the hypothesis that higher learning intent facilitates higher level of knowledge transfer and results showed its positive significant affect (Simonin, 2004). Moreover, it is also argued by some authors that if the firms in an alliance are highly motivated to learn from each other then they will be more psychologically prepared to understand each other's knowledge, skills and other know-how (Pérez-Nordtvedt et al., 2008). Another research by Easterby-Smith et al. (2008) mentioned the importance of learning intent in transferring knowledge in the 
US firms. Studies have tried to measure the learning intent of the alliance partners by asking questions on their intentions to learn knowledge and skills of their partner firms at the time of alliance formation and during it (Simonin, 2004).

\subsection{Partner protectiveness}

In strategic alliances, some partners are tend to be less open than the others (Hamel, 1991). Authors like Inkpen (1998), says that the learning process depends upon the degree of protectionism of the partners as it determines the level of accessibility of knowledge. In case of joint ventures, the two forces work opposite to each other, first is the need to cooperate which demands partners' resource sharing while second is the desire of protecting their core competencies (García-Canal and Llaneza, 1998). Inkpen (2000) researched the important conditions under which joint ventures' firms exploit the learning opportunities where knowledge spill-overs are said to be inevitable in joint ventures but the degree of partner protectiveness tends to influence the knowledge spill-over effects which help in attaining competitive advantages over competitors. Simonin (2004) again tested an organisational learning model using a cross-sectional sample of 147 international alliances where one of the main determinants was the extent of protectiveness where it was found to increase the ambiguity of knowledge thus hampering the knowledge exchange. The NUMMI alliance of General Motors and Toyota where General Motors was keen to learn Toyota's manufacturing practices and Toyota wanted to gain information regarding US's local conditions to manage them but both of them protected their core competencies of Toyota's small manufacturing skills and GM's US dealership management (Kale et al., 2000; Inkpen, 2008). Recent researches show that the non-equity alliances are favoured even though they provide lower levels of protection because of their flexible structures and potential learning opportunities (Osborn and Hagedoorn, 1997).

\subsection{Cultural distance}

In Matsumoto's (1996) terms, culture can be defined as the "set of attitudes, values, beliefs and behaviours shared by a group of people, but different for each individual, communicated from one generation to the next" (Spencer-Oatey, 2012). While Hofstede (2011) refers to culture as, "the collective programming of the mind that distinguishes the members of one group or category of people from others." Johanson and Vahlne defined cultural distance as "the resulting vector of culture based factors that impede the flow of information between the firms and its partner or environment" (Simonin, 1999b). Inkpen (1998) emphasized the importance of cultural compatibility among alliance partners for ensuring the learning and knowledge acquisition. Simonin (1999b) hypothesised the positive relationship of cultural distance with knowledge ambiguity, thus hampering knowledge transfer among international alliance partners which resulted in significant relationship thus proving the importance of national culture in knowledge management. Studies on cross-border alliances' learning have highlighted the importance of national cultural differences and their influence on the learning intent and ability of the alliance partners (Tidd and Izumimoto, 2002). Researchers have proved that national cultural differences negatively impact the knowledge spill-overs in international strategic alliances thus hampering the alliance success (Lane et al., 2001a). In alliances, cultural 
distance tends to increase barriers in identifying and understanding partner's competitive advantage as well as in understanding the local market mechanisms and hampers the process of grasping opportunities due to cultural differences (Simonin, 1999b). Difficulties in knowledge transfer in international alliances are exaggerated by the partners' cultural and language differences (Pérez-Nordtvedt et al., 2008). A study done on identification of the important factors affecting transnational knowledge transfer examined effect of cultural differences on the knowledge management process which was found to have a significant negative impact on knowledge transfer (Duan et al., 2010a).

\subsection{Rotation and training of employees}

Love (1995) theoretically examined the knowledge management in multinationals by critically analysing the Kogut and Zander's (1992) arguments regarding transaction cost, market failure and opportunism and highlighted the importance of training of employees for knowledge transfer. Training of employees in analogical reasoning can increase their knowledge transfer ability of some particular tasks or of some particular skills (Argote et al., 2003). A study on international joint ventures identified two major factors to maximise the impact of knowledge transfer which are IJV's strategy and its training competence, thus training is said to be an important variable in catalysing the transfer of both tacit and explicit knowledge (Lane et al., 2001b). Inkpen (2008) also highlighted many important factors of the knowledge transfer mechanism including rotation or transfer of employees and training programs. Training is viewed as an important channel of transferring knowledge via workshops (Duan et al., 2010b). Joint training programs are encouraged among the alliance partners to promote knowledge transfer and to improve the collaborative relationship among them. Sometimes, alliance's organisational structures are intended to be formally designed via proper documentation, forming cross-functional teams, rotating employees, arranging formal training sessions, etc. (Liu et al., 2010). Training programs are said to be effective in transferring knowledge which have characteristics like demonstrations and observations as it boosts both tacit and explicit knowledge transfer (Argote and Fahrenkopf, 2016).

\subsection{Knowledge transfer among alliance partners}

Resource-based view of the firm emphasises the importance of knowledge as a means of competitive advantage making it a key asset thus maximum number of international alliances are formed with the motive of knowledge acquisitions to become globally competitive. Simonin (1999b) empirically studied technological knowledge transfer on a cross-sectional sample of 147 strategic alliances and studied the impact of various variables impacting knowledge transfer. Knowledge transfer is said to be dependent upon the ease of transportation, interpretation and absorption (Simonin, 1999b). A study examined the strategies relating to knowledge exchange in international joint ventures formed between British and Japanese firms and listed 40 functions from which different functions are influenced by different parent in the venture (Tidd and Izumimoto, 2002). Another study by Simonin (2004) tested an organisational learning model with its antecedents like learning intent, knowledge ambiguity, partner protectiveness, etc. where learning intent and knowledge ambiguity emerged as the most significant determinants (Simonin, 2004). Pérez-Nordtvedt et al. (2008) examined a sample of 102 US organisations to study the effectiveness of cross-border knowledge transfer and 
found that the relationship between knowledge attributes and knowledge transfer is partially mediated by the recipient's learning intent and source attractiveness. Various other studies have linked knowledge properties and knowledge transfer to study its impact on alliance performance (Duan et al., 2010a; Chen et al., 2014; Lo, 2016).

Knowledge transfer is the process through which one entity (individual/team/ organisation) learns from the experience of another entity. It is considered as an important mechanism for performance improvement (Argote and Fahrenkopf, 2016). Literature has witnessed enormous studies on the antecedents and consequences of knowledge transfer (Simonin, 1999a, 1999b, 2004; Inkpen, 2000, 2008; Tsai, 2001; Rhodes et al., 2008; Duan et al., 2010b; Kang et al., 2010; Bellini et al., 2016). Knowledge is transferred in different ways according to its characteristics: tacit knowledge which is difficult to codify is transferred through formal or informal meetings, trainings, etc. while explicit knowledge which can be easily codified, is stored and shared usually through databases, communication networks like intranet/internet (Dhanaraj et al., 2004; Rhodes et al., 2008; Park et al., 2015). The result of knowledge transfer can be measured via various approaches like performance-based measurement approach as adopted in this study by means of innovation performance (Argote and Ingram, 2000).

\subsection{Absorptive capacity of the alliance}

Absorptive capacity is defined as the ability of a firm to understand the value of some new external information or knowledge to assimilate it, to gain competitive advantage (Cohen and Levinthal, 1990). Mowery et al. (1996) examined the inter-firm knowledge transfer in case of strategic alliances and found that higher levels of absorptive capacity helps a firm to exploit the technological and other knowledge in a better manner. Lack of absorptive capacity is also highlighted as a knowledge related barrier which hampers the effective use of transferred knowledge (Simonin, 1999a). A research by Szulanski studied 122 best practice transfer cases in eight large firms where internal knowledge exchange has been majorly hampered by the lack of absorptive capacity (Isobe et al., 2000). Results of a study by Salk et al. showed that absorptive capacity mediates the relationship between the knowledge transfer and IJV performance (Lane et al., 2001b). Tsai (2001) analysed data of 24 firms in petrochemical industry and 36 firms of food-manufacturing industry and Wang and Zhang (2009) researched on 151 corporations to study the effect of knowledge transfer in networks while considering the role of absorptive capacity which showed significant positive effect on innovation and other performances of the firm. Other studies also empirically studied the role of firm's absorptive capacity in internalising the transferred knowledge from the alliance partners on firms' innovation performance (Simonin, 2004; Szulanski and Jensen, 2004; Lyles and Salk, 2007). Many studies have focussed on the moderating effect of organisation's absorptive capacity on the relationship of knowledge transfer from alliance partners and innovation performance among which have researched on Chinese firms and found a positive significant impact of absorptive capacity on the relationship of knowledge transfer and innovation performance (Kim et al., 2011; Wang and Han, 2011).

Lack of absorptive capacity also dampens the process of knowledge transfer as suggested by various authors (Lane and Lubatkin, 1998; Lane et al., 2001a; Tsai, 2001; Minbaeva et al., 2003), thus making it a significant factor facilitating knowledge transfer. 


\subsection{Alliance's innovation performance}

Performance measurement of corporate houses is one of the most significant topics in business management. Zahra et al. (2000) studied the impact of international expansion on organisation's technological learning and finally learning's impact on financial performance. The FDI has been found to positively influence firm's learning but long-term learning is found to positively impact the firm's performance (Zahra et al., 2000). The strategic relationship between the knowledge transfer and alliance performance has also been empirically studied by Salk et al. and significant positive relationship was found between them (Lane et al., 2001b). A study which focussed on the knowledge transfer among the business units in a network found that the position of a firm in its network plays a crucial role in promoting innovation and other performances due to its access to knowledge of other firms but the role of absorptive capacity is also important for successful application of the knowledge acquired from other firms (Tsai, 2001). An empirical study on business units finds the relationship between knowledge properties and firm's innovation performance develops a theoretical model and uses a seven point Likert scale measuring performance variables like product innovation and managerial innovation. Results showed a negative relationship between knowledge properties like tacitness and innovation performance, a negative relationship between a network density and performance and a positive relationship between absorptive capacity and innovation performance (Wang and Zhang, 2009). Chen et al. (2009) used structural equation modelling to analyse the positive effects of the relationship learning on Taiwan firm's innovation performance which again used product and process innovation as performance constructs.

\section{Research gaps}

The theory of dynamic capabilities is being increasingly criticised for lacking properly defined constructs and empirical evidence (Burisch and Wohlgemuth, 2016). Thus, this study is an attempt to fulfil this research gap by providing an integrated research model on this theory. Moreover, not much research has focussed on International strategic alliances as a source of exchanging knowledge from firms across borders, this study will analyse knowledge exchange in a cross-industry framework. This study contributes to the existing literature pointing towards FDI as a vehicle of knowledge transfer among organisations of different national origin.

\section{Research objectives}

- To identify factors affecting knowledge transfer in an international strategic alliances.

- To study the impact of knowledge transfer on the alliances' innovation performance.

- To study the impact of absorptive capacity on the relationship of knowledge transfer and alliance performance. 


\section{Proposed research model}

Figure 1 Proposed research framework (see online version for colours)

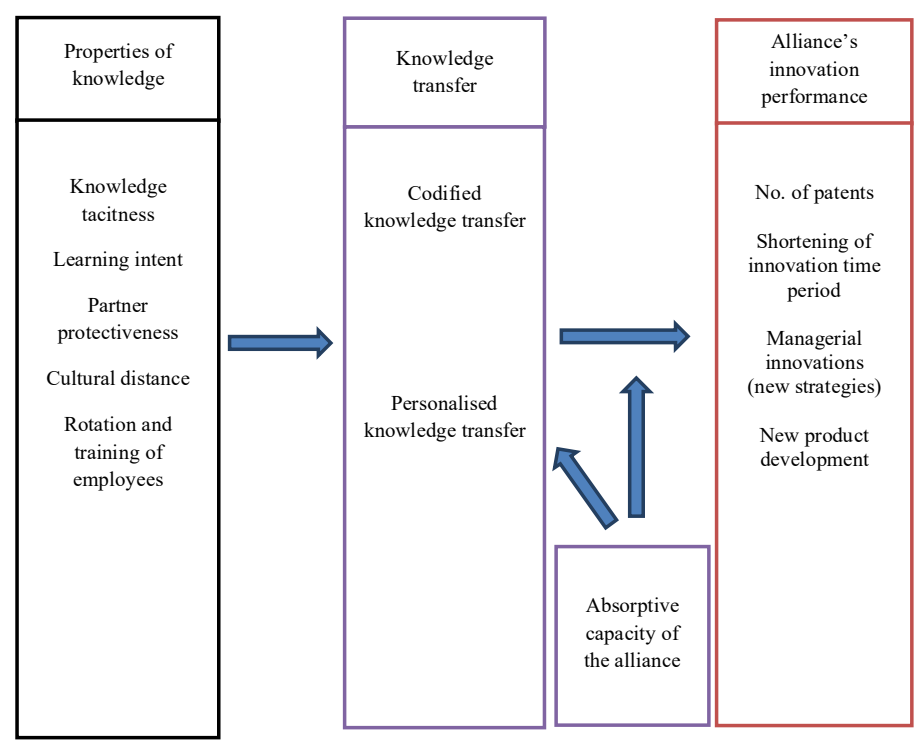

\section{Propositions (hypotheses) proposed}

Proposition 1: Knowledge tacitness negatively affects the knowledge transfer among alliance partners (Simonin, 1999a).

Proposition 2: Learning intent positively affects the knowledge transfer among alliance partners (Inkpen, 2000).

Proposition 3: Partner protectiveness negatively affects the knowledge transfer among alliance partners (Simonin, 1999a).

Proposition 4: Cultural distance between alliance partners negatively affects the knowledge transfer among alliance partners (Hsiao et al., 2016).

Proposition 5: Knowledge transfer in an alliance positively affects the alliance's innovation performance (Rhodes et al., 2008).

Proposition 6: The relationship between knowledge transfer in an alliance and its innovation performance is moderated/mediated by the absorptive capacity of the alliance (Cohen and Levinthal, 1990; Lane et al., 2001a; Wang and Han, 2011). 


\section{Proposed methodology}

The paper is conceptual in nature, but proposes a model to be empirically tested. Various dimensions of all the variables in the proposed model (Figure 1) will be identified. Standardised/adopted/adapted scales of variables covering all identified dimensions will be used to develop a questionnaire for empirical testing of the framework. The questionnaire will be subjected to academic and industry experts' validation before the commencement of data collection. All the international strategic alliances operating in India will form the population for this empirical research. Purposive sampling will be used to select the sample. This will be a pan India study. Middle and top level managers having appropriate knowledge of the concerned area will be the sampling units. Factor analysis and PLS-SEM will be applied to the collected data for validating the proposed model.

\section{Expected contribution to the literature}

The study systematically reviewed the vast literature available on knowledge transfer, international strategic alliances, innovation performance and absorptive capacity. The study will help in identifying organisational factors crucial for the knowledge transfer and finally success of the international strategic alliances' performance. After the review of literature, an integrated and comprehensive framework is proposed incorporating all the above mentioned elements. This study tries to build a framework incorporating dynamic capabilities theory which studies all the important factors affecting knowledge transfer to cope with the dynamic environment in order to attain sustainable competitive advantage. All the variables in the framework are the elements of this theory either directly or indirectly. This study provides a literature review for future researchers and also mentions the various dimensions of identified variables for future empirical testing. It will add to the existing international business, knowledge management and strategic management literature as it provides the important organisational factors for alliance better performance and the impact of knowledge transfer on the alliance's innovation performance. The study will also undertake the important role of alliance's absorptive capacity and will add to the literature by testing the role it plays in moderating/mediating the relationship of knowledge transfer and performance of international alliances in Indian context.

\section{References}

Argote, L. and Fahrenkopf, E. (2016) 'Knowledge transfer in organizations: the roles of members, tasks, tools, and networks', Organizational Behavior and Human Decision Processes, Vol. 136, No. 1, pp.146-159, Elsevier Inc.

Argote, L. and Ingram, P. (2000) 'Knowledge transfer: a basis for competitive advantage in firms', Organizational Behavior and Human Decision Processes, Vol. 82, No. 1, pp.150-169.

Argote, L., McEvily, B. and Reagans, R. (2003) 'Managing knowledge in organizations: an integrative framework and review of emerging themes', Management Science, Vol. 49, No. 4, pp.571-582. 
Bellini, A., Aarseth, W. and Hosseini, A. (2016) 'Effective knowledge transfer in successful partnering projects', Energy Procedia, Vol. 96, No. 1876, pp.218-228, DOI: 10.1016/j. egypro.2016.09.127.

Burisch, R. and Wohlgemuth, V. (2016) 'Blind spots of dynamic capabilities: a systems theoretic perspective', Journal of Innovation \& Knowledge, Vol. 1, No. 2, pp.109-116.

Chen, C.J., Hsiao, Y.C. and Chu, M.A. (2014) 'Transfer mechanisms and knowledge transfer: the cooperative competency perspective', Journal of Business Research, Vol. 67, No. 12, pp.2531-2541, Elsevier Inc. [online] http://dx.doi.org/10.1016/j.jbusres.2014.03.011.

Chen, Y-S., Lin, M-J.J. and Chang, C-H. (2009) 'The positive effects of relationship learning and absorptive capacity on innovation performance and competitive advantage in industrial markets', Industrial Marketing Management, Vol. 38, No. 2, pp.152-158, Elsevier Inc.

Cohen, W.M. and Levinthal, D.A. (1990) 'Absorptive capacity: a new perspective on learning and innovation', Administrative Science Quarterly, Vol. 35, No. 1, pp.128-152.

Davenport, T.H., De Long, D.W. and Beers, M.C. (1998) 'Building successful knowledge management projects', Sloan Management Review, Vol. 39, No. 2, pp.43-57.

Dhanaraj, C. et al. (2004) 'Managing tacit and explicit knowledge transfer in IJVs: the role of relational embeddedness and the impact on performance', Journal of International Business Studies, Vol. 35, No. 5, pp.428-442.

Duan, Y., Nie, W. and Coakes, E. (2010a) 'Identifying key factors affecting transnational knowledge transfer', Information \& Management, Vol. 47, Nos. 7-8, pp.356-363, DOI: 10.1016/j.im.2010.08.003.

Duan, Y., Nie, W. and Coakes, E. (2010b) 'Identifying key factors affecting transnational knowledge transfer', Information \& Management, Vol. 47, Nos. 7-8, pp.356-363, Elsevier BV, DOI: 10.1016/j.im.2010.08.003.

Easterby-Smith, M., Lyles, M.A. and Tsang, E.W.K. (2008) 'Inter-organizational knowledge transfer: current themes and future prospects', Journal of Management Studies, Vol. 45, No. 4, pp.677-690, DOI: 10.1111/j.1467-6486.2008.00773.x.

García-Canal, E. and Llaneza, A.V. (1998) 'Distinctive features of domestic and international joint ventures', MIR: Management International Review, Vol. 38, No. 1, pp.49-66.

Grant, R.M. (1991) 'The resource-based theory of competitive advantage: implications for strategy formulation', California Management Review, Vol. 33, No. 3, pp.114-135.

Hamel, G. (1991) 'Competition for competence and inter-partner learning within international strategic alliances', Strategic Management Journal, Vol. 12, No. 12, pp.83-103.

Hamel, G., Doz, Y.L. and Prahalad, C.K. (1989) 'Collaborate with your competitors and win', Harvard Business Review, Vol. 67, No. 1, pp.133-139.

Hofstede, G. (2011) 'Dimensionalizing cultures: the Hofstede model in context', Online Readings in Psychology and Culture, Vol. 2, No. 1, pp.1-26, DOI: 10.9707/2307-0919.1014.

Hsiao, Y. et al. (2016) 'Resource alignment, organizational distance, and knowledge transfer performance: the contingency role of alliance form', The Journal of Technology Transfer, Vol. 42, No. 3, pp.635-653, Springer, USA.

Inkpen, A.C. (1998) 'Learning and knowledge acquisition through international strategic alliances', The Academy of Management Executive, Vol. 12, No. 4, pp.69-80.

Inkpen, A.C. (2000) 'Learning through joint ventures: a framework of knowledge acquisition', Journal of Management Studies, Vol. 37, No. 7, pp.1019-1044.

Inkpen, A.C. (2008) 'Managing knowledge transfer in international alliances', Thunderbird International Business Review, Vol. 49, No. 5, pp.630-631.

Inkpen, A.C. and Beamish, P.W. (1997) 'Knowledge, bargaining power, and the instability of international joint ventures', The Academy of Management Review, Vol. 22, No. 1, pp.177-202.

Inkpen, A.C. and Tsang, E.W.K. (2005) 'Social capital, networks and knowledge transfer', Academy of Management Review, Vol. 30, No. 1, pp.146-165. 
Isobe, T., Makino, S. and Montgomery, D.B. (2000) 'Resource commitment, entry timing, and market performance of foreign direct investments in emerging economies: the case of Japanese international joint ventures in China', Academy of Management Journal, Vol. 43, No. 3, pp.468-484.

Kale, P., Singh, H. and Perlmutter, H. (2000) 'Learning and protection of proprietary assets in strategic alliances: building relational capital', Strategic Management Journal, Vol. 21, No. 3, pp. 217-237.

Kang, J., Rhee, M. and Kang, K.H. (2010) 'Revisiting knowledge transfer: effects of knowledge characteristics on organizational effort for knowledge transfer', Expert Systems with Applications, Vol. 37, No. 12, pp.8155-8160, Elsevier Ltd., DOI: 10.1016/j.eswa.2010. 05.072 .

Kim, C., Zhan, W. and Krishna Erramilli, M. (2011) 'Resources and performance of international joint ventures: the moderating role of absorptive capacity', Journal of Asia Business Studies, Vol. 5, No. 2, pp.145-160.

Kogut, B. and Zander, U. (1992) 'Knowledge of the firm, combinative capabilities, and the replication of technology', Organization Science, Vol. 3, No. 3, pp.383-397.

Kogut, B. and Zander, U. (2003) 'Knowledge of the firm and the evolutionary theory of the multinational corporation', Journal of International Business Studies, Vol. 34, No. 6, pp.516-529.

Lane, P.J. and Lubatkin, M. (1998) 'Relative absorptive capacity and interorganizational learning', Strategic Management Journal, Vol. 19, No. 5, pp.461-477.

Lane, P.J., Salk, J.E. and Lyles, M.A. (2001a) 'Absorptive capacity, learning, and performance in international joint ventures', Strategic Management Journal, Vol. 22, No. 12, pp.1139-1161, DOI: $10.1002 / \mathrm{smj} .206$.

Lane, P.J., Salk, J.E. and Lyles, M.A. (2001b) 'Absorptive capacity, learning, and performance in international joint ventures', Strategic Management Journal, Vol. 22, No. 12, pp.1139-1161.

Lei, D., Slocum, J.W. and Pitts, R.A. (1997) 'Building cooperative advantage: managing strategic alliances to promote organizational learning', Journal of World Business, Vol. 32, No. 3, pp.203-223, DOI: 10.1016/S1090-9516(97)90008-0.

Liu, C.L.E., Ghauri, P.N. and Sinkovics, R.R. (2010) 'Understanding the impact of relational capital and organizational learning on alliance outcomes', Journal of World Business, Vol. 45, No. 3, pp.237-249, Elsevier Inc., DOI: 10.1016/j.jwb.2009.09.005.

Lo, F.Y. (2016) 'Intra-MNE advantage transfer and subsidiary innovativeness: the moderating effect of international diversification', Journal of Business Research, Vol. 69, No. 5, pp.1712-1717, Elsevier Inc.

Love, J.H. (1995) 'Knowledge, market failure and the multinational enterprise: a theoretical note', Journal of International Business Studies, Vol. 26, No. 2, pp.417-426.

Lyles, M.A. and Salk, J.E. (2007) 'Knowledge acquisition from foreign parents in international joint ventures: an empirical examination in the Hungarian context', Journal of International Business Studies, Vol. 38, No. 5, pp.3-18.

Madhok, A. and Phene, A. (2003) 'The co-evolutional advantage: Strategic management theory and the eclectic paradigm', International Journal of the Economics of Business, January, Vol. 1516, pp.84-97, DOI: 10.4324/9780203576427.

Minbaeva, D. et al. (2003) 'MNC knowledge transfer, subsidray absorptive capacity, and HRM', Journal of International Business Studies, Vol. 34, No. 6, pp.586-599.

Mowery, D.C., Oxley, J.E. and Silverman, B. (1996) 'Strategic alliances and interfirm knowledge transfer', Strategic Management Journal, Winter special issue, Vol. 17, No. S2, pp.77-91.

Nonaka, I. (1994) 'A dynamic theory of organizational knowledge creation', Organization Science, Vol. 5, No. 1, pp.14-37, DOI: 10.1287/orsc.5.1.14.

Osborn, R.N. and Hagedoorn, J. (1997) 'The institutionalization and evolutionary dynamics of interorganizational alliances and networks', The Academy of Management Journal, Vol. 40, No. 2, pp.261-278. 
Park, C., Vertinsky, I. and Becerra, M. (2015) 'Transfers of tacit vs. explicit knowledge and performance in international joint ventures: the role of age', International Business Review, Vol. 24, No. 1, pp.89-101, Elsevier Ltd.

Pérez-Nordtvedt, L. et al. (2008) 'Effectiveness and efficiency of cross-border knowledge transfer: an empirical examination', Journal of Management Studies, Vol. 45, No. 4, pp.714-744, DOI: $10.1111 / \mathrm{j} .1467-6486.2008 .00767 . x$.

Reagans, R. and Mcevily, B. (2003) 'Network structure and knowledge transfer: the effects of cohesion and range', Administrative Science, Vol. 48, No. 2, pp.240-267.

Reed, R. and Defillippi, R.J. (1990) 'Casual ambiguity, barriers to imitation, and sustainable competitive advantage', The Academy of Management Review, Vol. 15, No. 1, pp.88-102.

Rhodes, J. et al. (2008) 'Factors influencing organizational knowledge transfer: implication for corporate performance', Journal of Knowledge Management, Vol. 12, No. 3, pp.84-100.

Riege, A. (2007) 'Actions to overcome knowledge transfer barriers in MNCs', Journal of Knowledge Management, Vol. 11, No. 1, pp.48-67, DOI: 10.1108/13673270710728231.

Simonin, B.L. (1999a) 'Ambiguity and the process of knowledge transfer in strategic alliances', Strategic Management Journal, Vol. 20, No. 7, pp.595-623.

Simonin, B.L. (1999b) 'Transfer of marketing know-how in international strategic alliances: an empirical investigation of the role and antecedents of knowledge ambiguity', Journal of International Business Studies, Vol. 30, No. 3, pp.463-490.

Simonin, B.L. (2004) 'An empirical investigation of the process of knowledge transfer in international strategic alliances', Journal of International Business Studies, Vol. 35, No. 5, pp.407-427.

Spencer-Oatey, H. (2012) What is Culture?, compiled by GlobalPAD Core Concepts.

Szulanski, G. and Jensen, R.J. (2004) 'When and how trustworthiness matters: knowledge transfer and the moderating effect of causal ambiguity', Organization Science, Vol. 15, No. 5, pp.600-613.

Teece, D.J. (2010) Technological innovation and the theory of the firm: the role of enterprise-level knowledge, complementarities, and (dynamic) capabilities', Handbook of the Economics of Innovation, Elsevier BV.

Teece, D.J. (2017) 'A capability theory of the firm: an economics and (strategic) management perspective', New Zealand Economic Papers, Vol. 51, pp.1-43, Taylor \& Francis.

Teece, D.J., Pisano, G. and Shuen, A. (1997) 'Dynamic capabilities and strategic management', Strategic Management Journal, Vol. 18, No. 7, pp.509-533.

Tidd, J. and Izumimoto, Y. (2002) 'Knowledge exchange and learning through international joint ventures: an Anglo-Japanese experience', Technovation, Vol. 22, No. 3, pp.137-145, DOI: 10.1016/S0166-4972(01)00006-2.

Tsai, W. (2001) 'Knowledge transfer in intraorganizational networks: effects of network position and absorptive capacity on business unit innovation and performance', The Academy of Management Journal, Vol. 44, No. 5, pp.996-1004.

Vaidya, S. (2009) 'International joint ventures: an integrated framework', Competitiveness Review, Vol. 19, No. 1, pp.8-16.

Wang, C. and Han, Y. (2011) 'Linking properties of knowledge with innovation performance: the moderate role of absorptive capacity', Journal of Knowledge Management, Vol. 15, No. 5, pp.802-819.

Wang, C-f. and Zhang, P. (2009) 'An empirical study on the relationship between properties of knowledge, network topology and corporation innovation performance', in International Conference on Management Science and Engineering - 16th Annual Conference Proceedings, ICMSE 2009, pp.1230-1237 [online] https://www.scopus.com/inward/record.uri?eid=2-s2.0$72249109601 \&$ partnerID=40\&md5=6ce04b84070c3bf25a33766e $129 \mathrm{~b} 642 \mathrm{a}$. 
Yli-Renko, H., Autio, E. and Sapienza, H.J. (2001) 'Social capital, knowledge acquisition, and knowledge exploitation in young technology-based firms', Strategic Management Journal, Vol. 22, Nos. 6-7, pp.587-613.

Young-Ybarra, C. and Wiersema, M. (1999) 'Strategic flexibility in information technology alliances: the influence of transaction cost economics and social exchange theory', Organization Science, Vol. 10, No. 4, pp.439-459, DOI: 10.1287/orsc.10.4.439.

Zahra, S.A., Ireland, R.D. and Hitt, M.A. (2000) 'International expansion by new venture firms: international diversity, mode of market entry, technological learning, and performance', The Academy of Management Journal, Vol. 43, No. 5, pp.925-950.

Zander, U. and Kogut, B. (1995) 'Knowledge and the speed of the transfer and imitation of organizational capabilities: an empirical test', Organization Science, Vol. 6, No. 1, pp.76-92. 